\title{
Response of two newly selected onion strains at different plant population
}

\begin{abstract}
Performance of two onion strains: NARC Onion-1 and NARC Onion-2, along with "phulkara" variety as check, were tested for a range of plant spacing $[6,8,10$ (control), $12 \& 14 \mathrm{~cm}]$. NARC Onion-2 excel in plant height, leaf \& bulb size and bulb yield and was found an early maturing strain among all three entries. Treatment with less populated plants $(14 \mathrm{~cm})$ showed highest bulb diameter and weight with delayed maturity for both newly selected onion strains. However, better yield was recorded from densely populated treatment of $6 \mathrm{~cm}$ and early maturing crop from $8 \mathrm{~cm}$.
\end{abstract}

Keywords: onion, allium cepa 1 , plant spacing, yield

\author{
Volume 2 Issue I - 2018 \\ Hidayatullah,' Haroon Aslam Khan, ${ }^{2}$ Ghulam \\ Jillani ${ }^{3}$ \\ 'PSO Directorate of Vegetable, DHR\&D, NARC Islamabad, \\ Pakistan \\ ${ }^{2}$ Student Gomal University Dera Ismail Khan, KPK, Pakistan \\ ${ }^{3}$ PSO/Director Directorate of Vegetable DHR\&D NARC \\ Islamabad, Pakistan
}

Correspondence: Hidayatullah, PSO Directorate of Vegetable,
DHR\&D, NARC Islamabad, Pakistan, Email hidayatu_2003@yahoo.co.uk

Received: July 26, 2017 | Published: January 30, 2018

\section{Introduction}

Onion (Allium cepa L.) is being grown over an area of 134 thousand hectares with the production of 1740 thousand tonnes (Fruit, vegetable and condiments statistics of Pakistan, 2013-14). Different and very limited number of varieties grown in different ecological zones of Pakistan includes Phulkara, Swat-1, Sariab Red, Chiltan-89, Desi Red and Nasarpuri. There always remains need to widen the genetic diversity in onion. Therefore germplasm (five entries) received from Asian Vegetable Research and Development Centre (AVRDC), Taiwan, was primarily evaluated during 2005-06 and 2006-07 along with six cultivated varieties of onion for yield and yield contributing factors at Directorate of Vegetable, NARC. Two selections (NARC Onion-1 \& NARC Onion-2) gave better performance with respect to yield. So there is a need to standardize other agronomical and crop management practices (e.g. fertilizer requirement, spacing \& planting time etc) for the said best performing strains. Plant population has a large influence on onion bulb size at harvest because plant competition and lack of available space can restrict bulb enlargement. Environmental factors, crop cultivars and cultural practices have great effect on the yield and quality of the onion crop. ${ }^{1}$ Studies from different scientists showed that wider spacing produced larger sized bulbs as compared to closest spacing. ${ }^{2-4}$ Rumpel et al. ${ }^{5}$ had obtained maximum marketable yield with smaller bulb size from high density plants $(80 \mathrm{p} /$ $\mathrm{m}^{2}$ ) as compared to densities of 40 and $60 \mathrm{p} / \mathrm{m}^{2}$. Also onion cultivars respond differently to different plant densities. Dawar et al. ${ }^{6}$ reported that lower planting density $\left(40\right.$ plants $\left./ 4 \mathrm{~m}^{2}\right)$ in three onion varieties (Swat-1, Terich-02 and Gilassi local) increased the bulb weight as compared to 60,80 plants $/ 4 \mathrm{~m}^{2}$. Therefore a study was planned during the cropping year 2011-12 to standardize plant spacing for the said onion strains (NARC Onion-1 \& NARC Onion-2).

\section{Materials and methods}

The experiment was carried out at the experimental field of Directorate of Vegetable, National Agricultural Research Centre (NARC), Islamabad. Seedlings of two onion strains (NARC Onion-1 \& NARC Onion-2) along with Phulkara as check were raised in the month of October, 2011. Healthy seedlings were transplanted in field on January 11, 2012. Five plant spacing/plant densities $[6,8,10$ (check), 12 and $14 \mathrm{~cm}$ or $67,50,40,33$ and $\left.29 \mathrm{p} / \mathrm{m}^{2}\right]$ with row-row distance keeping constant $(25 \mathrm{~cm})$ were compared. All fertilizer requirements $\&$ cultural practices were performed according to recommendations. Physiological parameters such as plant height $(\mathrm{cm})$, number of leaves, leaf length and width were recorded at 80 days after transplanting (DAT). Crop was harvested at neck fall. Maturity days of the crop, bulb yield and other bulb related parameters; bulb size \& weight were recorded at harvest. The experiment was carried out under factorial design with three replications per treatment. Data was analyzed with Statistix 8.1 and treatment means were compared for significance with LSD test.

\section{Results and discussion}

\section{Plant Height (cm)}

NARC Onion-2 attained maximum plant height at all plant spacing evaluated as compared to NARC Onion-1 and Phulkara (check), both having non-significant difference among each other (Figure 1). However, in another study by Jillani et al., "Phulkara" cultivar excelled in all physiological and yield related parameters including plant height against other varieties tested in that study. Alteration in plant population $\left(29-67 \mathrm{p} / \mathrm{m}^{2}\right)$ could not show any significant effect on plant height of the selected onion strains (Figure 1). Previous studies, however, reported that widest plant spacing $(20-25 \mathrm{~cm})$ of respective experiments produced maximum plant height. ${ }^{1-4}$

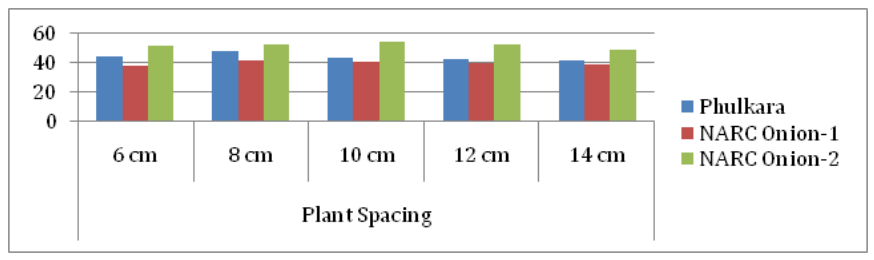

Figure I Plant height $(\mathrm{cm})$ of onion genotypes at 80 DAT as affected by plant spacing. 


\section{Number of leaves}

Both onion strains (NARC Onion-1 \& NARC Onion-2) produced as number of leaves as that of Phulkara used as check. Also increase or decrease in plant spacing compared to control $(10 \mathrm{~cm})$ had not affected significantly number of leaves per plant (Figure 2). Our results are opposite to Dharmendra et al., ${ }^{2}$ Khan et al., ${ }^{3}$ Dawar et al. ${ }^{6}$ which showed that wider spacing produced maximum number of green leaves compared to closer spacing.

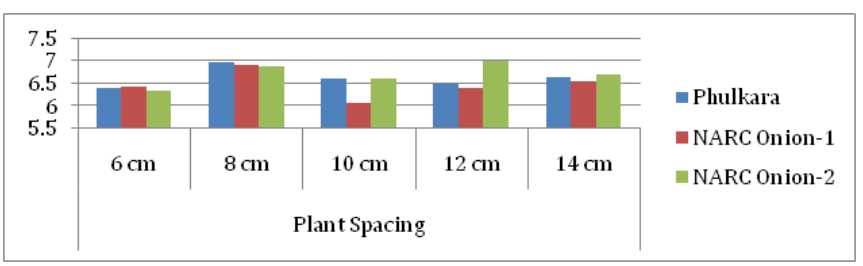

Figure 2 Number of leaves of onion genotypes at 80 DAT as affected by plant spacing.

\section{Leaf length $(\mathrm{cm})$}

NARC Onion-2 had significantly longer leaves compared to other two entries at all plant densities which may be a varietal character (Figure 3). However, Jillani et al. ${ }^{4}$ reported longer leaves in Phulkara compared to other varieties. Plant spacing had not shown any effect on leaf length (Figure 3). Contradictory results had been reported by Khan et al., ${ }^{3}$ Dawar et al. ${ }^{6}$ Khan et al. ${ }^{3}$ reported that wider spaced plants produced maximum leaf length while Dawar et al. ${ }^{6}$ reported that closed spaced plants treatment produces better results.

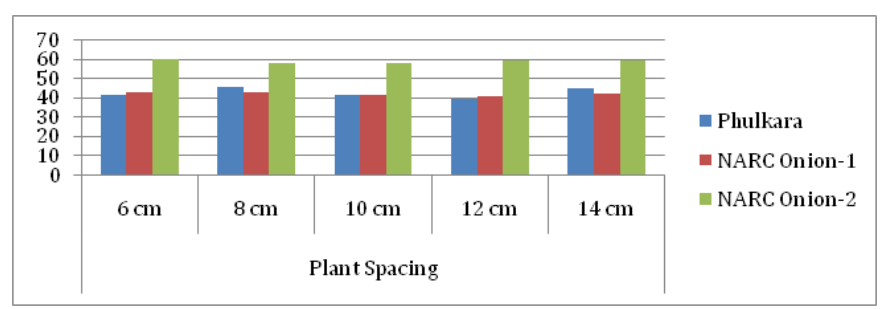

Figure 3 Leaf length $(\mathrm{cm})$ of onion genotypes at 100 DAT as affected by plant spacing.

\section{Leaf width $\mathbf{( c m )}$}

NARC Onion-2, with the wider leaf sheath resulted better, compared to others. Plant population $/ \mathrm{m}^{2}$ had not any significant effect on leaf width (Figure 4). However in earlier studies, wider spacing (20x20) showed maximum leaf diameter compared to closer spacing. ${ }^{2}$ Interaction showed a clear varietal difference on the increase of plant spacing compared to control (Figure 4).

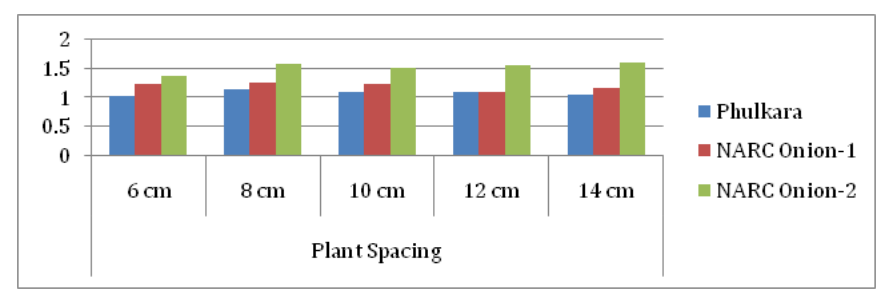

Figure 4 Leaf width $(\mathrm{cm})$ of onion genotypes at 100 DAT as affected by plant spacing.

\section{Days to maturity}

A significant difference for maturity days was observed among two onion strains and control (Phulkara). Onion strain NARC-2 proved early maturing compared to other two entries. Beside this, with the decrease in plant population, a significant delay in maturity was observed (Figure 5). Early maturity was recorded at plant spacing of $8 \mathrm{~cm}$. Rumpel et al. ${ }^{5}$ also reported, that plant density hastened the maturity of onion to some extent.

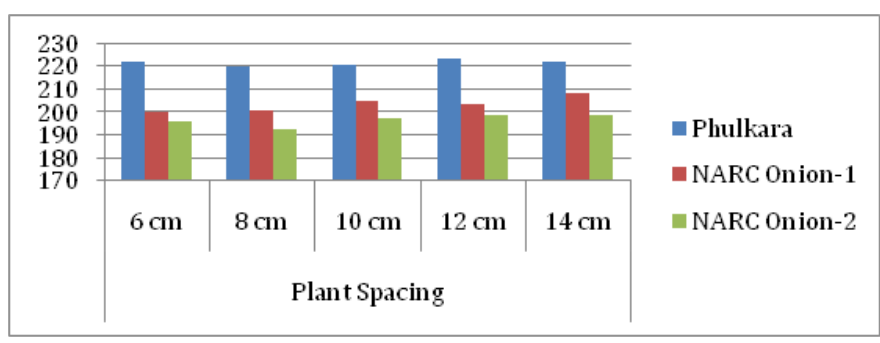

Figure 5 Days to maturity of onion genotypes as affected by plant spacing.

Bulb Size (Length $\mathbf{x}$ diameter): NARC Onion-2 had significantly better bulb size (Figure 7)(Figure 8) compared to NARC Onion-1 and Phulkara (check) which produced maximum bulb diameter in another study. ${ }^{4}$ Bulb diameter increased significantly with decrease in plant population (Figure 6) in spite of bulb length (Figure 6) which had not taken any effect of these treatments. Dharmendra et al., ${ }^{2}$ Jillani et al., ${ }^{4}$ Khan et al. ${ }^{3}$ results are also confirmatory with our results. They reported that wider spaced plants produced maximum bulb size. However, Khan et al. ${ }^{1}$ stated that more spaced plants produce medium bulbs.

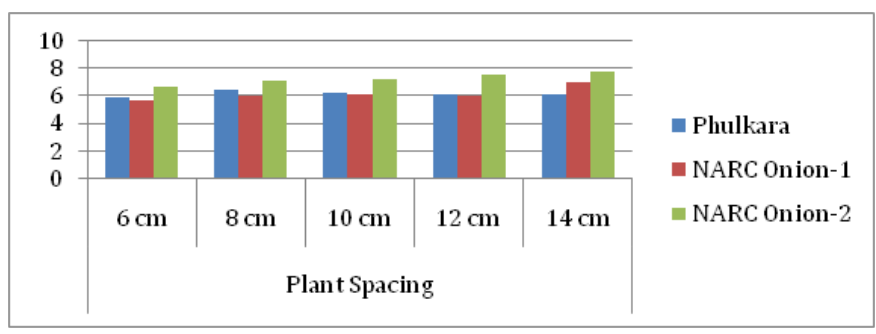

Figure 6 Bulb diameter $(\mathrm{cm})$ of onion genotypes as affected by plant spacing.

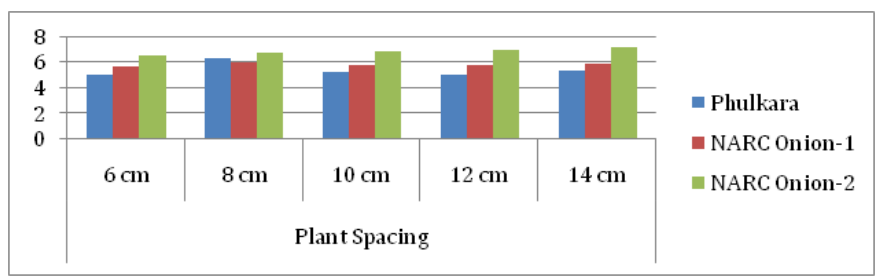

Figure 7 Bulb length $(\mathrm{cm})$ of onion genotypes at 80 DAS as affected by plant spacing.

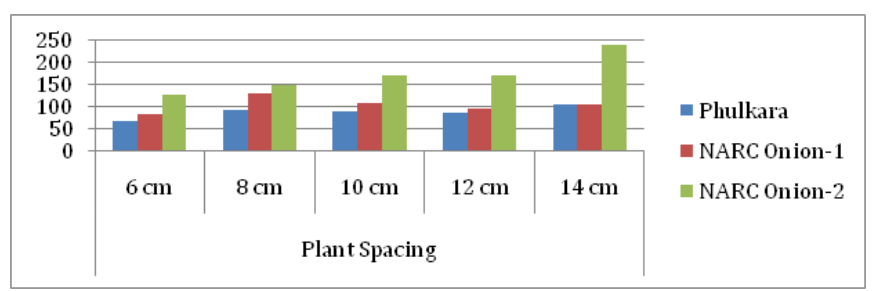

Figure 8 Bulb weight $(\mathrm{g})$ of onion genotypes at harvest as affected by plant spacing.

\section{Bulb weight (g)}

NARC Onion-2 had more weighty bulbs (Figure 8) as compared to other two entries with clear and significant difference at maximum 
spacing $(14 \mathrm{~cm})$. Bulb weight increased significantly with the decrease in plant population. However, plant spacing from $8-12 \mathrm{~cm}$ showed at par results (Figure 8). Previous researchers also reported that increased plant density resulted in reduction of bulb weight. ${ }^{2-7}$ Yield $(\mathrm{t} / \mathrm{ha})$ NARC Onion-2 resulted in significant more yield ( $t / h a)$ as compared to NARC Onion-1 and Phulkara (Figure 9). NARC Onion-1 had no significant difference with Phulkara in yield. However Phulkara out yielded other local varieties in another study as reported by Jillani et al. ${ }^{4}$ Plant spacing treatment of $6 \mathrm{~cm}$ slightly increased yield (Figure 9 ) as compared to check $(10 \mathrm{~cm})$. However, previous studies reported significant increase in yield with the increase in plant density. ${ }^{1-10}$

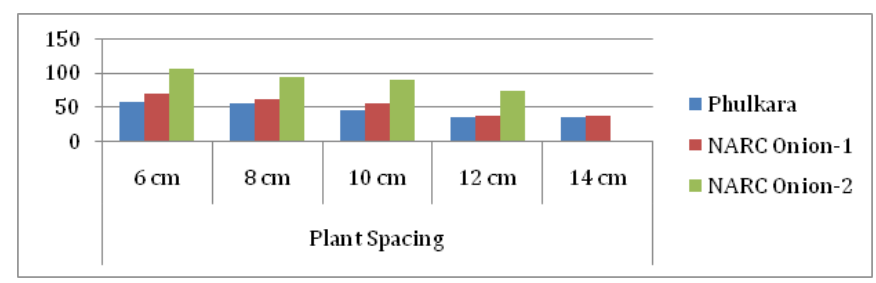

Figure 9 Bulb yield ( $t / h a)$ of onion genotypes at harvest as affected by plant spacing.

\section{Conclusion}

NARC Onion-2 excel in plant height, leaf \& bulb size and bulb yield and was also found an early maturing strain among all three entries. However, better yield was recorded from densely populated treatment of $6 \mathrm{~cm}$ and early maturing crop from $8 \mathrm{~cm}$.

\section{Acknowledgements}

None.

\section{Conflict of interest}

The author declares no conflict of interest.

\section{References}

1. Khan H, Iqbal M, Ghafoor A, et al. Effect of various plant spacing and different Nitrogen levels on the growth and yield of onion (Allium cepa L.). J Biological sciences. 2002;2(8):545-547.

2. Dharmendra K, Singh PV, Kumar A. Effect of different levels of spacing on growth and yield of onion. Agric Sci Digest. 2001;21(2):139-140.

3. Khan MA, Hassan MK, Miah MAJ, et al. Effect of plant spacing on the growth and yield of different varieties of onion. Pakistan Journal of Biological Sciences. 2003;6(18):1582-1585.

4. Jillani MS, Ahmed P, Waseem K, et al. Effect of plant spacing on growth and yield of two varieties of onion (Allium cepa L.) under the agro climatic conditions of D.I Khan. Pakistan Journal of Science. 2010;62(1):37-41.

5. Rumpel J, Felczenski K. Effect of plant density on the yield and bulb size of direct sown onions. Acta Horticulturae. 2000;533:179-185.

6. Dawar NM, Wazir FK, Dawar MUD, et al. Effect of planting density on growth and yield of onion varieties under climatic conditions of Peshawar. Sarhad J Agric. 2007;23(4):911-918.

7. Chaudhry MF, Mahmood K, Khan MA, et al. Effect of plant density on plant growth, size and yield of onion. Pakistan J Agric Res. 1990;11(4):239-242.

8. Barakauskienzi Z, Dris R, Oladele OI. Effects of row spacing and seed rate on onion quality and yield. Nigerian J Horticulture Science. 2002;7(1):22-25.

9. Awas G, Abdisa T, Tolesa K, et al. Effect of intra row spacing on yield of three onion varieties. Journal of Horticulture and Forestry. 2010;2(1):007-011.

10. GOP. Fruit, Vegetable and Condments Statistics of Pakistan 2013-14. Ministry of Food Security \& Research, Economic wing, Islamabad, Pakistan; 2014. p. 1-44. 